\title{
Production and production risk of broiler farms In the Regency of North Minahasa - Indonesia
}

\author{
Erwin Wantasen*1), Sintya J.K. Umboh ${ }^{1)}$, Jein. R Leke ${ }^{2)}$, Florencia. N. Sompie ${ }^{3)}$ \\ 1) Department of Socio-Economic, Faculty of Animal Husbandry, Sam Ratulangi University, \\ Manado, 95115, Indonesia \\ 2) Department of Animal Production, Faculty of Animal Husbandry, Sam Ratulangi \\ University, Manado, 95115, Indonesia \\ 3) Department of Feed and Nutrition, Faculty of Animal Husbandry, Sam Ratulangi \\ University, Manado, 95115, Indonesia
}

Submitted: 06 June 2020, Accepted: 08 June 2021

\begin{abstract}
The broiler is one of the potential husbandry commodities to be developed, but its development faces various risks, particularly production risk. This is indicated by fluctuating mortality of broiler in each period. This research aimed to analyze some production factors determining production and production risk of broiler production activity in the Regency of North Minahasa, Province of North Sulawesi. In addition, the research's site was purposively determined, such as six villages representing three districts (District of Dimembe, Kauditan, and Kalawat) having the largest population of breeders under partnership program in the Regency of North Minahasa. From each village, then, breeders were selected by sampling method, comprising 27 breeders of Village of Dimembe, 18 breeders of Village of Matungkas, 19 breeders of Village of Kauditan Satu, 16 breeders of Village of Kauditan Dua, 13 breeders of Village of Kolongan and 10 breeders of Village of Suwaan. The sample of breeders was 100 respondents of the breeder. Further, data collected by survey and analyzed employing Just and Pope Analysis to know some production impacts against production and production risk of broiler. In conclusion, the research shows that the variable of a total of feed, heater, ammotrol, rice husk, and a total of labors could improve broiler production, and variable of Day Old Chick (DOC) could decrease broiler production. Variable of a total of feed, vitamin, rice husk, and a total of labors could decrease production risk of broiler, but a total of a day of chicks could increase production risk of broiler.
\end{abstract}

Keywords: Production; Production risks; DOC; Feeds; Labor

\footnotetext{
*Corresponding Author: erwinwantasen@yahoo.co.id
} 


\section{INTRODUCTION}

One of regencies in Province of North Sulawesi becoming the center of broiler cultivation is the Regency of North Minahasa. In 2014, data of a total of poultry's meat production was derived from a total broiler population, 2,686,137 broilers, and it increased as many as 4,717,432 broilers in 2017 (BPS Kabupaten Minahasa Utara, 2018). It indicates that broiler husbandry activity in the Regency of North Minahasa has promising and potential prospects to be developed.

This broiler husbandry located in the Regency of North Minahasa is, indeed, feasible to have continuous development, but some breeders, especially in the Regency of North Minahasa, deal with several burdens, such as capital, feed, disease, and marketing in maintaining their business. Thus, partnership program can be pragmatic solution (Wantasen and Umboh, 2015; Ishag, 2019; Carvalhoet al., 2015; Fanani, Anggraeni and Syaukat, 2015).One of the partnership programs located in the Regency of North Minahasa and having operated since 2010 was PT. Charoen Pokphan Jaya Farm, having a responsibility to fulfill broiler farm's input such as feed, Day old chick (DOC), medicines and providing certainty on selling price of broiler's products and assuring quality against the production of broiler produced.

However, there is another issue dealt with by breeders related to the fluctuation of broiler's productivity. Based on the data collected, there was a decreasing product of 2,686,137 broilers (2014) turning into $2,633,127$ broilers (2015). In addition, there was an improvement of 4,717,432 broilers in 2017, but its population decreased in 2018, such as 4,634,323 broilers (Dinas Pertanian dan Peternakan Kabupaten Minahasa Utara, 2019). The presence of long-period of the dry and raining season across 2015 and 2018 and breeders' behavior in managing their broiler's business are assumedly considered as supporting factors of risk occurrence against broiler's production and production cost in the Regency of North Minahasa. It is proven that climate, weather, and disease become a source of risks in determining the performance of broiler's production and health (Mir et al., 2017; Majid and Hassan, 2014; Salois, Cady, and Heskett, 2016; Ramadhan, Yektiningsih and Sudiyarto, 2018; Obike, Amusa and Olowalafe, 2017; Ximenes, Trisuniwati and Muharlien, 2018). Previously, some researches have focused on the analysis of production, productivity, and various determining risks as well (Gocsik et al., 2014; Baracho et al., 2019; Mendes et al., 2014; Mosnier et al., 2009; Mir et al., 2017). Meanwhile, research on production risk of broiler is still limited on the identification of numerous potential risks, such as external factors or difficultly controlled factors by breeders (Obike, Amusa, and Olowalafe, 2017; Martindah, Ilham and Basuno, 2014; Iheke and Igbelina, 2016; Ishag, 2019).

Production risk dealt with broiler's breeders in the Regency of North Minahasa does not only come from external factors, such as climate change, disease, weather, price instability, financial facility, marketing competition, and government regulation but also derives from internal factors, namely breeder's behavior in utilizing production factors. Sometimes, these local breeders using production factors, such as Day Old Chick (DOC), vitamins, and medicines ignore the standard of procedure technically required and advised by the main Company. Hence, it is assumed to become a risk factor of declining broiler productivity. Several production factors used comprise DOC, feed, rice husk, heater, labor, vitamin, medicines, vaccine, and odor exhauster of a cage (ammotrol). These factors of production can be both riskreducing factors and risk-inducing factors. Non-optimization of production input usage can cause fluctuate occurrence of broiler's productivity and production risk (Calduch $e t$ al., 2012; Martindah et al., 2014; Lewerin et al., 2015). Therefore, this research is 
purposively aimed to analyze determining factors of broiler's production improvement and reducing or inducing factors of broiler's production risk under partnership program in the Regency of North Minahasa, conducted between PT. Charoen Pokphan Jaya Farm and plasma breeders that it has not been previously performed.

\section{MATERIALS AND METHODS Research Location}

The research's site was purposively determined in the Regency of North Minahasa as the center of broiler production in the Province of North Sulawesi. Then, three Districts, having breeders already cooperated for 5 years with the main Company, PT. Charoen Pokphand Jaya Farm, as distributor of production input, was purposively selected. Those three Districts had $50 \%$ of the broiler's population among 10 Districts existing in this area, which were the District of Dimembe, Kauditan, and Kalawat. Data collecting for the research was performed on March-May 2019 using the survey method (Mishra and Alok, 2017). The type of data used was primary and secondary. Primary data was obtained through in-depth interviews using a questionnaire against broiler breeders partnered with PT. Charoen Pokphan Jaya Farm, consisting of characteristics of the breeder (name, age, and education), an overview of broiler cultivation, rate data of broiler's production, rate of production factors usage, and data of broiler's mortality during 5 production periods in 2018 (on March, May, July, September, and November). Besides the interview, recording and observation of conditions surrounding husbandry were performed as well. While secondary data was gained through the journal of animal husbandry (derived from the internet), Board of Central Statistic (BPS) of Sulut, Service of Agriculture and Animal Husbandry of Regency of North Minahasa, literature review, reference books of economy and agriculture. Specifically, secondary data focused on the total broiler's population and a total of broiler's breeders, climate, and weather.

\section{Sampling Technique of Breeder}

Purposively, in each District, two villages having the largest population of broiler's breeders were selected. Particularly, in the District of Dimembe, the Village of Dimembe (27 breeders) and the Village of Matungkas (18 breeders) were selected. In the District of Kauditan, the Village of Kauditan Satu (19 breeders) and Kauditan Dua (16 breeders) were chosen, and, in the District of Kalawat, Village of Kolongan (13 breeders) and Village of Suwaan (10 breeders) were selected as sample. All breeders existing in each village were selected by totally sampling (Silalahi, 2015), so the total of breeder samples was 100 breeders.

\section{Method of Data Analysis}

To know determining factors of broiler's production and production risk, cultivated under partnership program, analysis model of Cobb Douglas and Just and Pope were employed (Just and Pope, 1979; Koundouri and Nauges, 2005), as the following formulation:

$Y=f(X, \beta)+h(X, \theta) \epsilon$

Where:

$\mathrm{Y}=$ Total of production resulted; $\mathrm{f}$ and $\mathrm{h}=$ Transforming production factors into result of production; $\mathrm{X}=$ Production factors used in production process; $\beta$ and $\theta=$ estimated coefficient; $\epsilon=$ error term 
$\operatorname{Max} \operatorname{EU}(\pi)=\mathrm{EU}[\operatorname{Pf}(\mathrm{x}, \beta)+\operatorname{Ph}(\mathrm{x}, \theta) \mathrm{e}-\mathrm{rx}]$

$\mathrm{r} / \mathrm{p}=\delta \mathrm{f}(\mathrm{x}) / \delta \mathrm{x}+\delta \mathrm{h}(\mathrm{x}) / \delta \mathrm{x} \quad \mathrm{X} \mathrm{E}\left(\mathrm{U}^{\prime} \mathrm{e}\right) / \mathrm{E}\left(\mathrm{U}^{\prime}\right)$

Where:

$\mathrm{U}$ is the Utility function of Von Newman Morgenstern, $\pi$ is profit, $\mathrm{P}$ is the unit of output price and $\mathrm{r}$ is the vector from a unit of output price. Whereas any breeder included in risk averter with $U \neq 0$ and optimal input of $x$ could not be determined from production function $F$, distortion of risk evading was shown in the following formulation:

$\delta \mathrm{h}(\mathrm{x}) / \delta \mathrm{x} X \mathrm{E}\left(\mathrm{U}^{\prime} \mathrm{e}\right) / \mathrm{E}\left(\mathrm{U}^{\prime}\right)$

If a sign of $\delta \mathrm{h}(\mathrm{x}) / \delta \mathrm{x}$ was positive, the production factor of $\mathrm{x}$ could increase production risk. While, if a sign showed negative, the production factor could decrease production risk.

The above production function consisted of two combinations of function, such as a function of output production (mean of production function), transforming input variables into production function, and production function having been added its risk element, which considered variance element of such production function. To solve the calculation of production function and variance of production, a function of Cobb Douglass was utilized, so that the function production model of Just and Pope could be mathematically written as follows:

Production Function

$\mathrm{Y} \quad=\mathrm{f}(\mathrm{X})$

$\operatorname{LnY} \quad=\beta 0+\beta 1 \operatorname{LnX} 1+\beta 2 \operatorname{LnX} 2+\beta 3 \operatorname{LnX} 3+\beta 4 \operatorname{LnX} 4+\beta 5 \operatorname{LnX} 5+\beta 6 \operatorname{LnX} 6+$ $\beta 7 \operatorname{LnX} 7+\beta 8 \operatorname{LnX} 8+\beta 9 \operatorname{LnX} 9+\beta 10 \operatorname{LnX} 10+\beta 11 \operatorname{LnX} 11+$ $\varepsilon \ldots \ldots \ldots \ldots \ldots \ldots . . .(6)$

The variance of Productivity:

$\sigma^{2} \quad=\mathrm{f}$

$(\mathrm{X})$.

(

$\alpha^{2} \mathrm{Y} \quad=(\mathrm{Yi}-\overline{\mathrm{Y}} \mathrm{i})^{2}$

Where:

$\sigma^{2} \mathrm{Y}=$ Production risk (Variance of Production);

$\mathrm{Yi}=$ Productivity;

$\overline{\mathrm{Y}} \mathrm{i}=$ Average productivity,

Thus, function of production risk (variance of production) was as follows:

$\operatorname{Ln} \sigma^{2} \mathrm{Y}=\theta 0+\theta 1 \operatorname{LnX} 1+\theta 2 \operatorname{LnX} 2+\theta 3 \operatorname{LnX} 3+\theta 4 \operatorname{LnX} 4+\theta 5 \operatorname{LnX} 5+\theta 6 \operatorname{LnX} 6+\theta 7 \operatorname{LnX} 7+$ $\Theta 8 \operatorname{LnX} 8+\theta 9 \operatorname{LnX} 9+\theta 10 \operatorname{LnX} 10+\theta 11 \operatorname{LnX} 11+\epsilon$

Where:

$\mathrm{Y}=$ Productivity of broiler $(\mathrm{gr} / \mathrm{broiler} /$ day $)$

$\mathrm{X} 1=$ Total of DOC $($ chick $/ \mathrm{m} 2)$

$\mathrm{X} 2 \quad=$ Feed $(\mathrm{gr} / \mathrm{broiler} / \mathrm{day})$

X3 $\quad=$ Protect Enro $(\mathrm{gr} / \mathrm{broiler} /$ day $)$

X4 $\quad$ Neocamp $(\mathrm{ml} /$ broiler/day $)$

X5 $\quad=$ Doxerin Plus (gr/broiler/day)

X6 $\quad=$ Vaccine $(\mathrm{gr} /$ broiler/day $)$

$\mathrm{X} 7 \quad=$ Vitamin $(\mathrm{gr} / \mathrm{broiler} /$ day $)$

X8 $=$ Ammotrol (odor exhauster of cage) $(\mathrm{gr} / \mathrm{broiler} / \mathrm{day})$ 


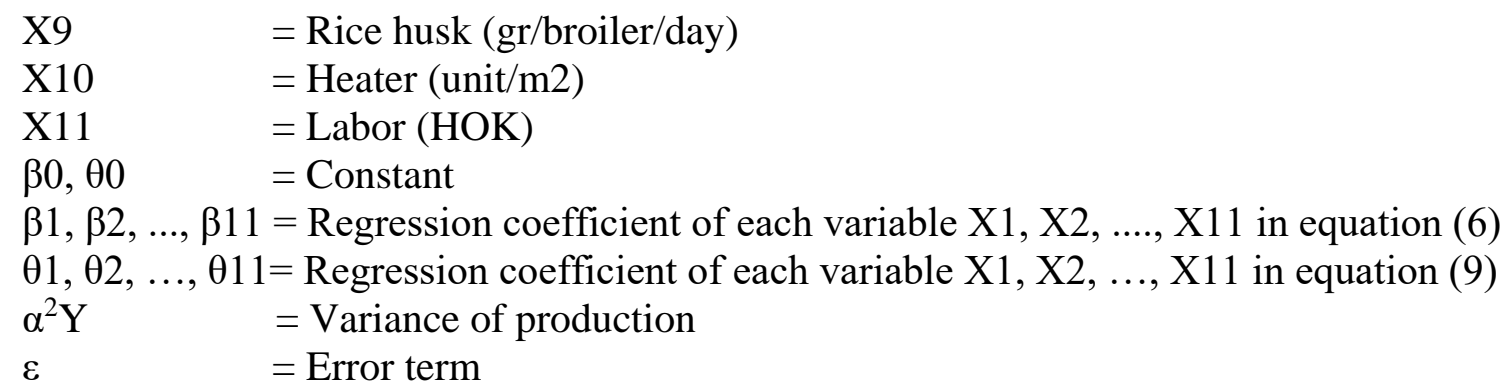

The broiler's productivity employed in this research of broiler was found out by calculating the bodyweight of the broiler (harvest time) and deduced with the weight of DOC (first time entered in a cage). To know joint impacts of all independent variables against broiler's production, $\mathrm{F}$ test was performed, as follows:

$$
\mathrm{F} \text { count }=\frac{R^{2} /(k-1)}{1-R^{2} /(n-k)}
$$

$\mathrm{R}^{2}=$ Coefficient of determination; $\mathrm{k}=$ Total of independent variables; $\mathrm{n}=$ Total of sample

If $\mathrm{F}$ count $>\mathrm{F}$ table $(\alpha=0.05)$, meaning the independent variables used simultaneously could affect the variable of broiler's production and production risk. Then, if $F$ count $<F$ table $(\alpha=0.05)$, showing that independent variable used simultaneously did not impact against the variable of broiler's the production and production risk.

To know the partial impact of each independent variable against the broiler's production and production risk (variance of production), a T-statistic test was used as follows:

T-statistic test of broiler's production:

$\mathrm{T}$ count $=\beta \mathrm{i} / \mathrm{S} \beta \mathrm{i}$

Where:

$\beta i=$ Regression coefficient of $i$ th variable; $S \beta i=$ Deviation standard of $\beta i$

T-statistic test of broiler's production risk:

$\mathrm{T}$ count $=\theta \mathrm{i} / \mathrm{S} \theta \mathrm{i}$

Where:

$\theta \mathrm{i}=$ Regression coefficient of $\mathrm{ith}$ variable; $\mathrm{S} \theta \mathrm{i}=$ Deviation standard of $\theta \mathrm{i}$

If the value of $\mathrm{T}$ count $>$ value of $\mathrm{T}$ table $(\alpha: 0.05 ; \mathrm{db}=\mathrm{n}-\mathrm{k}-1)$, the partially independent variable significantly impacted on broiler's production and production risk. While, if the value of $\mathrm{T}$ count $<$ value of $\mathrm{T}$ table $(\alpha: 0.05 ; \mathrm{db}=\mathrm{n}-\mathrm{k}-1)$, the partially independent variable did not impact on broiler's production and production risk.

\section{Hypothesis Test of Ordinary Leat Square (OLS)}

The hypothesis test model was performed with the OLS method. However, some hypotheses following OLS, such as multicollinearity and heteroskedasticity
(Gujarati and Porter, 2010), were previously tested. Multicollinearity of the independent variable is a condition where linear relation between independent variables exists. It can be seen from the value of Variance Inflation Factor (VIF) $>10$. If there is a multicollinearity issue, it has previously to be fixed by including observation and excluding firmly correlated independent variables. Hence, heteroskedasticity occurs if residual variances are different. This can be detected through Glejser text, using a regressing independent variable with its residual absolute value. If the significant 
value of an independent variable with residual absolute is more than 0,05 , heteroskedasticity is fine.

\section{RESULT AND DISCUSSION Characteristics of Respondent}

Table 1 demonstrates that broiler breeders in the Regency of North Minahasa were typically relatively young, graduated from Senior High School averagely, and having long business experience in broiler husbandry (about 10 years).

This data is similar to Ridwan and Amrawaty (2018), stating that though broiler breeders were relatively young, their experience was long enough so that it correlated with responsibility and skills in managing their business. The long experience in broiler husbandry was that many breeders started their business previously as labor in a cage, and, consequently, they had direct knowledge and knew all technical aspects before establishing their broiler husbandry.

Most breeders had a scale of business of 1,000 - 3,000 broilers, mostly having an area of the cage between $0 \mathrm{~m}^{2}-500 \mathrm{~m}^{2}$. In addition, ownership of cage and area from broiler's breeders in the Regency of North Minahasa only consisted of two ownerships, private and lease of the cage. Lease of the cage was performed since some breeders did not have the strategy is to construct their cage, so the lease was the alternative way using a periodical leasing system or annual leasing.

Table 1. Characteristics of respondent

\begin{tabular}{lcc}
\hline Characteristics of respondent & Total (respondent) & Percentage (\%) \\
\hline Age (Year) & 53 & 53 \\
$20-39$ & 37 & 37 \\
$40-59$ & 10 & 10 \\
$\geq 60$ & & \\
Education & 24 & 24 \\
Elementary School & 33 & 33 \\
Junior High School & 38 & 38 \\
$\quad$ Senior High School & 3 & 5 \\
University & & \\
Experience (Year) & 78 & 78 \\
$1-10$ & 17 & 5 \\
$11-20$ & 5 & 79 \\
$\geq 21$ & & 16 \\
Business Scale (Broiler) & 79 & 5 \\
$1,000-3,000$ & 16 & 49 \\
$3,001-5,000$ & 5 & 40 \\
$\geq 5,000$ & & 11 \\
Area of Cage $\left(\mathrm{M}^{2}\right)$ & 49 & \\
$0-299$ & 40 & \\
$300-499$ & 11 & \\
$\geq 500$ & &
\end{tabular}

\section{Multicollinearity Test}

One of the purposes of the regressionanalysis model conducted to analyze some effects of production factor against broiler's production and production risk is to assure that resulted model does not violate any requirements, such as the existence of independent variable experiencing multicollinearity where there is linear relation among independent variables. The result of the multicollinearity test is shown in following Table 2. 
Table 2. Multicollinearity test among variables

\begin{tabular}{lrrrrr}
\hline \multicolumn{1}{c}{ Predictors } & Coefficient & SE coefficient & \multicolumn{1}{c}{ T } & P & VIF \\
\hline Constant & -2.721 & 0.152 & -17.890 & 0.000 & \\
DOC (x1) & -0.572 & 0.045 & -12.580 & 0.000 & 5.4 \\
Feed (x2) & 0.332 & 0.041 & 8.090 & 0.000 & 2.5 \\
Protect Enro(x3) & 0.002 & 0.013 & 0.150 & 0.880 & 1.7 \\
Neocamp(x4) & 0.014 & 0.013 & -1.100 & 0.279 & 1.6 \\
Doxerin plus(x5) & -0.026 & 0.012 & 2.160 & 0.036 & 1.7 \\
Vaccine (x6) & -0.025 & 0.027 & 0.930 & 0.356 & 2.8 \\
Vitamin(x7) & -0.184 & 0.018 & 1.217 & 0.224 & 1.9 \\
Ammotrol(x8) & 0.079 & 0.032 & 2.473 & 0.025 & 2.2 \\
Rice husk (x9) & 0.393 & 0.035 & 2.376 & 0.024 & 1.6 \\
Heater (x10) & 3.257 & 0.113 & 28.760 & 0.000 & 6.8 \\
Labor (x11) & -0.086 & 0.009 & 8.740 & 0.000 & 1.2 \\
\hline
\end{tabular}

Table 2, shows that all variables did not contain multicollinearity. It can be seen from the value of VIF. All variables shown had a value of VIF $<10$ so that such a model was free from multicollinearity (Gujarati and Porter, 2010). After such variables did not contain multicollinearity, a test was conducted against the analysis model whether there was heteroscedasticity or not.
Therefore, the Glejser test was done, which its result can be viewed in the following Table 3.

According to the analysis result with the Glejser test in Table 3, it displays that all significant values of independent variables were bigger than 0.05 , so it can be concluded that heteroscedasticity was zero from the data obtained.

Table 3. Heteroscedasticity test of production tests against broiler's production risk

\begin{tabular}{lc}
\hline \multirow{2}{*}{ Independent variables } & Value \\
\cline { 2 - 2 } & Probability (Sig) \\
\hline DOC (x1) & 0.103 \\
Feed (x2) & 0.236 \\
Protect Enro(x3) & 0.505 \\
Neocamp(x4) & 0.144 \\
Doxerin plus(x5) & 0.327 \\
Vaccine (x6) & 0.462 \\
Vitamin(x7) & 0.108 \\
Ammotrol(x8) & 0.235 \\
Rice husk (x9) & 0.418 \\
Heater (x10) & 0.114 \\
Labor (x11) & 0.351 \\
\hline
\end{tabular}

\section{Production Factors Influence of Broiler's Production}

Broiler's production from a breeder as plasma or partner from PT Charoen Pokphan Jaya Farm was influenced by several production inputs. Inducing the production factor of broiler's production can be seen from the analysis result of the mean production function, shown in the following Table 4. In detail, the presumed result of the mean production function describes that the value of the F-count of 18.473 had a significant impact at one percent $(\mathrm{P}<0.01)$. This means that independent variables jointly provided a significant impact against broiler's productivity of plasma breeders. Further, the result of the analysis postulates that the production function of the broiler provided the value of determination coefficient $\left(\mathrm{R}^{2}\right)$ of $80.5 \%$ and adjusted $\mathrm{R}^{2}$ of 
79.6\%. The partial variable providing significant and positive impact against broiler's production was total of feed, ammotrol, rice husk, heater, and a total of labors $(\mathrm{P}<0.05)$, while variable of a total of DOC had a negative and significant impact $(\mathrm{P}<0.05)$ against broiler's production. Variable of ammotrol, consisting of herbal extract used to eliminate cage's odor had a positive impact against broiler's productivity since it could neutralize ammonia contained in broiler's carcass inside the cage and prevent broiler from CRD (Chronic Respiratory Disease) so that it improved broiler's productivity.

Other variables such as to protect enro, neocamp, doxerin plus, vaccine, and vitamin did not partially provide significant impact against broiler's production. Total of DOC (Day Old Chick) had a negative impact against broiler's production since breeders placed a total of DOC within per $\mathrm{m}^{2}$ of cage's area, exceeding requirements, so this treatment disturbed broiler's growth.

Table 4. Analysis of influencing factors of broiler's production

\begin{tabular}{lccc}
\hline \multicolumn{1}{c}{ Variables } & Coefficient & t- stat & Probability \\
\hline Constant & -4.842 & -10.739 & 0.000 \\
DOC (X1) & -0.648 & -11.117 & $0.000^{*}$ \\
Feed (X2) & 0.364 & 6.025 & $0.000^{*}$ \\
Protect Enro (X3) & 0.021 & 0.086 & 0.775 \\
Neocamp (X4) & 0.023 & 0.643 & 0.301 \\
Doxerin plus (X5) & -0.032 & -1.634 & 0.104 \\
Vaccine (X6) & -0.038 & -0.680 & 0.327 \\
Vitamin (X7) & 0.172 & 1.514 & 0.129 \\
Ammotrol (X8) & 0.068 & 2.754 & $0.024^{*}$ \\
Rice husk (X9) & 0.371 & 3.580 & $0.004^{*}$ \\
Heater (X10) & 3.277 & 17.382 & $0.000^{*}$ \\
Labor (X11) & 0.078 & 6.375 & $0.000^{*}$ \\
\hline R Square & & & \\
Adjusted R Square & 0.796 & & \\
F count & 18.473 & & \\
Prob F Statistic & $0.000^{* *}$ & & \\
$*$ *significant level at5\% $(\mathrm{P}<0.05)$ & & \\
$* *$ significant level at $1 \%(\mathrm{P}<0.01)$ & &
\end{tabular}

Then, the variable of heater impacted against broiler's production since breeders installed heater within a cage, so it prevented broiler from cold weather. Such conditions would prevent broilers from using their meat to warm their body's temperature, and this circumstance could maintain their growth. Meanwhile, rice husk is used by breeders to maintain the cage's floor from wastecarrying disease, so broilers' growth was optimal. Labors used by breeders were experienced and skilled labor in cultivating broilers, so they were skillful in solving any issues. As result, the labor used had a positive and significant impact on broiler's production. These findings are in accordance with previous researches, arguing that broiler's productivity was influenced by input factors, such as feed, Day Old Chick (DOC), labor, vitamin, disinfectant, and heater (Nugraha et al., 2017; Ozsvari et al., 2017; Ike and Ugwumba, 2011; Abdurofi et al.,2017; Tuffour and Oppong, 2014)

\section{Production Factors Influence of Broiler's Production Risk}

The result of regression analysis against broiler husbandry under partnership program in the Regency of North Minahasa is presented in the following Table 5. Specifically, the analysis result from above Table 5 demonstrates that the variable of a 
total of feed, vitamin, rice husk, and labor contributed negative and significant impact $(\mathrm{P}<0.05)$ against broiler's production risk. Those variables could decrease broiler's production risk, viewed from negative sign in their regression coefficient respectively. Variable of a total of feed could decrease broiler's production risk since breeders had applied to feed in accordance with broiler's age, so that standard need of broiler could be fulfilled. Rice husk could decline broiler's production risk since it could keep cage's floor in dry condition so that it prevented broiler from disease infection. Also, vitamins could maintain the broiler's metabolism and fitness and reduce stress, so it could improve the broiler's appetite and productivity.

Labors employed by breeders were familial labor having knowledge and experience in cultivating broiler, so it could solve various issues. Therefore, skilled and experienced familial laborers could reduce production risk. Those were the result of the partnership program of PT Charoen Pokphan Jaya Farm, periodically providing consultation and guidance to plasma breeders.

Table 5. Analysis of Influencing Factors of Broiler's Production Risk

\begin{tabular}{|c|c|c|c|}
\hline Variables & Coefficient & t- stat & Probability \\
\hline Constant & 0.001 & 0.224 & 0.787 \\
\hline DOC (X1) & 0.211 & 0.123 & 0.899 \\
\hline Feed (X2) & -0.003 & -2.774 & $0.048 *$ \\
\hline Protect Enro (X3) & $3.33 \mathrm{E}-05$ & 0.050 & 0.957 \\
\hline Neocamp (X4) & $-3.25 \mathrm{E}-05$ & -0.046 & 0.961 \\
\hline Doxerin plus (X5) & $-4.36 \mathrm{E}-05$ & -0.052 & 0.903 \\
\hline Vaccine (X6) & 0.003 & 0.057 & 0.953 \\
\hline Vitamin (X7) & -2.108 & -3.526 & $0.031 *$ \\
\hline Ammotrol (X8) & -0.204 & -0.231 & 0.714 \\
\hline Rice husk (X9) & -9.343 & -3.754 & $0.014 *$ \\
\hline Heater (X10) & -0.002 & -0.034 & 0.967 \\
\hline Labor (X11) & -0.005 & -2.998 & $0.043 *$ \\
\hline R Square & 0.748 & & \\
\hline Adjusted R Square & 0.706 & & \\
\hline F Statistic & 15.06 & & $0.000 *$ \\
\hline
\end{tabular}

*: Significant level at $5 \%(\mathrm{P}<0.05)$

However, the variable of a total of DOC, health program, and vaccine, not specifically providing significant impact $(\mathrm{P}>0.05)$ against broiler's production risk, tended to increase broiler's production risk, shown with a positive value of regression coefficient.

Total of DOC, not in accordance with cage's size where $1 \mathrm{~m}^{2}$ was filled by 12 broilers of DOC (Day Old Chick), resulted in disturbed productivity of broiler, so it increased production risk. Health protection could increase broiler's production risk since breeders used similar dosages in variously different scales of business, so its impact was insignificant and tended to reduce productivity. Variable of vaccine could increase broiler's production risk in the Regency of North Minahasa since breeders sometimes gave unsuitable dosage and plasma company sometimes delayed in distributing broiler to plasma breeders, so it could decrease broiler's productivity and increase broiler's production risk. This result is in line with Adepoju, Timothy, and Oyekale (2013), Gocsik et al.(2017), and Suwarta and Hanafie (2018), stating that factors of breeder's behavior, DOC cost, cost of feed, the dosage of drug and vaccine and business volume had a significant impact against broiler's production risk and income risk. 


\section{CONCLUSIONS}

Some production factors in determining broiler's production under partnership program in the Regency of North Minahasa are a total of DOC (Day of Chick), a total of feed, rice husk, heater, and labor. On the other hand, production factors of vitamin, rice husk, and labor have a significant impact in decreasing production risk, and factor of a total of Day of Chick (DOC), vaccine, and health protection program has insignificant impact against production risk, but it tends to increase broiler's production risk in the Regency of North Minahasa.

\section{ACKNOWLEDGMENT}

We would sincerely thank the Directorate of Research and Public Service (DRPM) of Ristek Dikti, having officially funded our research under the Priority Fundamental Research Scheme of Higher Education of 2019, and members of the researcher's team for their active and cooperative participation in completing this research.

\section{REFERENCES}

Abdurofi, I., Ismail, M. M., Kamal, H. A. W., \& Gabdo, B. H. (2017). Economic analysis of broiler production in Peninsular Malaysia. International Food Research Journal, 24(4), 761-766.

Adepoju, A. O., Timothy, O. A., \& Oyekale, A. S. (2013). Risk coping behaviour of small scale poultry farmers in ogun state, Nigeria. Asian Journal of Animal and Veterinary Advances, 8(6), 786-795. https://doi.org/10.392 3/ajava.2013.786.795

Adytia Nugraha, Y., Nissa, K., Nurbaeti, N., Muhammad Amrullah, F., \& Wahyu Harjanti, D. (2017). Pertambahan bobot badan dan feed conversion rate ayam broiler yang dipelihara menggunakan desinfektan herbal. Jurnal Ilmu-Ilmu Peternakan, 27(2), 19-24. https://doi.org/10.21776/ub.ji ip.2017.027.02.03

Baracho, M., Nääs, I., Lima, N., Cordeiro,
A., \& Moura, D. (2019). Factors affecting broiler production: a metaanalysis. Brazilian Journal of Poultry Science, 21(3), 1-10. https://doi.org/ 10.1590/1806-9061-2019-1052

BPS Kabupaten Minahasa Utara. (2018). Kabupaten Minahasa Utara Dalam Angka 2017.

Calduch, E.N., Elfadaly, S., Tibbo, M., Ankers, P., \& Bailey, E. (2012). Assessment of biosecurity practices of small scale broiler producers on Central Egypt. Preventive Veterinary Medicine, 110, 253-262

Carvalho, E., Zilli, J., Mendes, A., Morello, G., \& Bonamigo, D. (2015). Main factors that affect the economic efficiency of broiler breeder production. Revista Brasileira de Ciência Avícola, 17(1), 11-16. https:// doi.org/10.1590/1516-635x170111-16

Dinas Pertanian dan Peternakan Kabupaten Minahasa Utara. (2019). Jumlah Peternak Ayam Pedaging di Kabupaten Minahasa Utara. Kantor Dinas Pertanian dan Peternakan Kabupaten Minahasa Utara.

Fanani, A., Anggraeni, L., \& Syaukat, Y. (2015). Pengaruh kemitraan terhadap risiko usaha tani tembakau di Kabupaten Bojonegoro Provinsi Jawa Timur. Jurnal Manajemen Dan Agribisnis, 12(3), 194-203. https://doi .org/10.17358/JMA.12.3.194

Gocsik, É., Kortes, H. E., Lansink, A. G. J. M. O., \& Saatkamp, H. W. (2014). Effects of different broiler production systems on health care costs in the Netherlands. Poultry Science, 93(6), 1301-1317. https://doi.org/10.3382/ ps.2013-03614

Gocsik, É., Silvera, A. M., Hansson, H., Saatkamp, H. W., \& Blokhuis, H. J. (2017). Exploring the economic potential of reducing broiler lameness. British Poultry Science, 58(4), 337347. https://doi.org/10.1080/0007166 8.2017.1304530

Gujarati, D., \& Porter, D. (2010). Essentials of Econometrics (4th ed.). Mc Grow Hill. 
Iheke, O., \& Igbelina, C. (2016). Risk management in poultry production in Ikeduru local government area of Imo State, Nigeria. Nigerian Journal of Agriculture, Food and Environment, 12(1), 67-74.

Ike, P. C., \& Ugwumba, C. O. A. (2011). Profitability of small scale broiler production in Onitsha North Local Government Area of Anambra State, Nigeria. International Journal of Poultry Science, 10(2), 106-109. https: //doi.org/10.3923/ijps.2011.106.109

Ishag, K. H. (2019). Broiler production systems risk management sustainability and feed subsidy policy analysis. IOSR Journal of Agriculture and Veterinary Science, 12(9), 33-44.

Just, R. E., \& Pope, R. D. (1979). Production function estimation and related risk considerations. American Journal of Agricultural Economics, 61(2), 276284. https://doi.org/10.2307/1239732

Koundouri, P., \& Nauges, C. (2005). On production function estimation with selectivity and risk considerations. Journal of Agricultural and Resource Economics, 30(3), 597-608. https:// doi.org/10.2307/40987295

Lewerin, S. S., Österberg, J., Alenius, S., Elvander, M., Fellström, C., Tråvén, M., Wallgren, P., Waller, K. P., \& Jacobson, M. (2015). Risk assessment as a tool for improving external biosecurity at farm level. $B M C$ Veterinary Research, 11(1), 171-183. https://doi.org/10.1186/s12917-0150477-7

Majid, R. Bin, \& Hassan, S. (2014). Performance of broiler contract farmers: a case study in Perak, Malaysia. UMK Procedia, 1, 18-25. https://doi.org/10.1016/j.umkpro.201 4.07.003

Martindah, E., Ilham, N., \& Basuno, E. (2014). Biosecurity level of poultry production cluster (PPC) in West Java, Indonesia. International Journal of Poultry Science, 13(7), 408-415. https: //doi.org/10.3923/ijps.2014.408.415
Mendes, A., Gudoski, D., Cargnelutti, A., Silva, E., Carvalho, E., \& Morello, G. (2014). Factors that impact the financial performance of broiler production in southern states of Paraná, Brazil. Revista Brasileira de Ciência Avícola, 16(1), 113-119. https://doi.org/10.1590/S1516-635X2 014000100016

Mir, N. A., Rafiq, A., Kumar, F., Singh, V., \& Shukla, V. (2017). Determinants of broiler chicken meat quality and factors affecting them: a review. Journal of Food Science and Technology, 54(10), 2997-3009. https: //doi.org/10.1007/s13197-017-2789-z

Mishra, S., \& Alok, S. (2017). Handbook of Reseach Methodology (1st ed.). Edureaction Publishing.

Mosnier, C., Reynaud, A., Thomas, A., Lherm, M., \& Agabriel, J. (2009). Eatimating a producton function under production and output price risk. In $A n$ application to beef cattle in France (pp. 9-46). Research Group : Environmetal Economics and Natural Resources.

Negro-Calduch, E., Elfadaly, S., Tibbo, M., Ankers, P., \& Bailey, E. (2013). Assessment of biosecurity practices of small-scale broiler producers in central Egypt. Preventive Veterinary Medicine, 110(2), 253-262. https://doi .org/10.1016/j.prevetmed.2012.11.014

Obike, K. C., Amusa, T. A., \& Olowolafe, H. B. (2018). Risk management and determinants of farm output among small scale poultry farmers in Ekiti State, Nigeria. Agro-Science, 16(2), 9. https://doi.org/10.4314/as.v16i2.2

Phan Dang, T., Vu Dinh, T., Duquesne, B., \& Lebailly, P. (2010). Analysis of risks and impacts on the incomes of small poultry producers in $\mathrm{Ha}$ Tay Province, North-Vietnam. Globalization of Tropical Animal Diseases and Public Health Concerns. Proceedings of the 13th Association of Institutions for Tropical Veterinary Medicine (AITVM) Conference, Bangkok, 
Thailand, 23-26 August 2010.

Ramadhan, B. D., Yektiningsih, E., \& Sudiyarto, S. (2018). Analisis risiko usaha ayam pedaging di Kabupaten Mojokerto. Jurnal Ilmiah Sosio Agribis, 18(1), 77-92. https://doi.org/ 10.30742/jisa.v18i1.448

Ridwan, M., \& Amrawaty, A. (2018). Agribusiness partnership performance in empowering broiler breeders. Bulgarian Journal of Agricultural Science, 24(5), 750-758.

Salois, M.J., Cady, R.A., \& Heskett, E.A. (2016). The environmental and economic impact of withdrawing antibiotics from US broiler production. Journal of Food Distribution Research, 47 (1), 79-80

Silalahi, U. (2015). Metode Penelitian Sosial Kuantitatif. Refika Aditama.

Suwarta, S. (2018). The influence of business management on income and the risk of income in the broiler chicken farming. Journal of Socioeconomics and Development, 1(1). https://doi.org/10.31328/jsed.v $1 \mathrm{i} 1.520$

Tuffour, M., \& Oppong, B. A. (2014). Profit efficiency in broiler production: Evidence from Greater Accra region of Ghana. International Journal of Food and Agricultural Economics, 2(1), 23-32.

Wantasen, E., \& Umboh, S. J. (2015). Analisis Pendapatan Peternak Ayam Ras Pedaging Dengan Sistim Kemitraan Di Kecamatan Tondano Utara Kabupaten Minahasa. Universitas Sam Ratulangi Manado.

Ximenes, L., Trisunuwati, P., \& Muharlien, M. (2018). Performa produksi Broiler starter akibat cekaman panas dan perbedaan awal waktu pemberian pakan. Jurnal Ilmu-Ilmu Peternakan, 28(2), 158-167. https://doi.org/10.217 76/ub.jiip.2018.028.02.08 